\title{
PRELIMINARY STUDIES TO VALUE ENHANCEMENT OF THE OLD CITADEL IN ORIA, ALMERIA, SPAIN.
}

\author{
J. Moya-Muñoz $^{1, *}$, A. Gonzalez-Serrano ${ }^{2}$, F. Pinto-Puerto ${ }^{3}$ \\ ${ }^{1}$ FPI HAR-2016-78113-R. Dept. of Expresión Gráfica, Universidad de Sevilla, Spain - jmmunoz@us.es \\ ${ }^{2}$ Dept. of Construcciones Arquitectónicas I, Universidad de Sevilla, Spain - gserrano@us.es \\ ${ }^{3}$ Dept. of Expresión Gráfica, Universidad de Sevilla, Spain - fspp@us.es
}

\section{Commission II - WG II/8}

KEY WORDS: Wall, Rammed-earth, Photogrammetry, Stratigraphic analysis, Constructive-typological taxonomy, Pathology

\begin{abstract}
:
During the Nasrid Kingdom of Granada, the alcazaba of Oria (Old citadel) was considered one of the most outstanding medieval defensive ensembles in the province of Almeria. This defensive complex, located in the Almanzora Valley at an altitude of over a thousand metres, was built around the 12th-14th centuries and has been registered as an Asset of Cultural Interest since 1985. Nevertheless, unfortunate decisions to intervene in the monument and lack of maintenance facilitated the loss of most of its wall, which had been preserved until the twentieth century. Despite the critical situation of the complex, two sections of the rammed-earth wall are currently identified as standing. This study represents an opportunity to broaden the knowledge of this relevant wall structure and the characterisation of the rammed-earth reinforced wall with lime mortar layers. As a preliminary step towards the rammed-earth walls analysis, the graphic representation of wall elevations by photogrammetry tools is proposed. This technique allows to graphically define the morphology of the rammed-earth wall, to perform its typological analysis and constructive characterisation; and furthermore, to evaluate the state of constructive elements conservation by means of the identification of its damages. The information and results obtained will allow to establish the appropriate laboratory tests for the rammed-earth materials characterisation and to define a report that justifies the inexcusable need to consolidate and preserve them.
\end{abstract}

\section{INTRODUCTION}

The alcazaba of Oria (Qal'a, al-qasaba Uriya), built in the Middle Ages (between the 10th and 14th centuries or 12th and 13 th centuries, according to different researchers), was part of an elaborate defensive complex made up of towers, watchtowers, forts, bastions, castles, etc., which allowed territorial control over the Almanzora Valley (Figure 1).

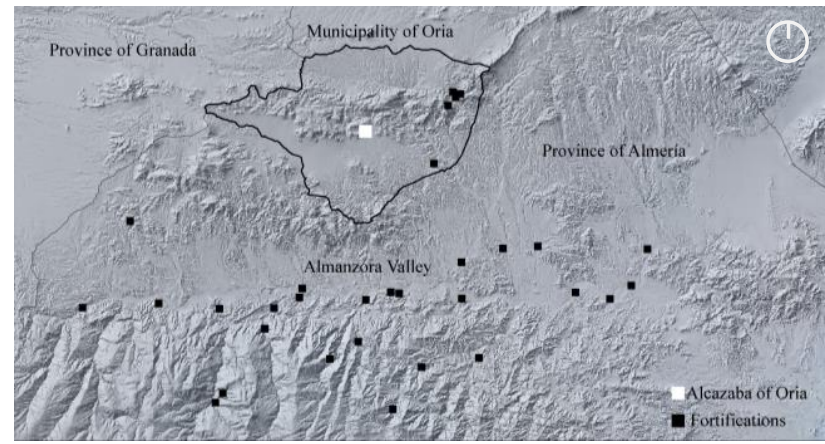

Figure 1. Fortifications of the Almanzora on a topographical relief plan. Source: the authors, using ArcGis 10.6.1 from the directory of Castellón, 2017.

The geographical location of this old citadel - over a thousand metres above sea level in 'Sierra de las Estancias' of the Almería province, Spain - and its topographical conditions made this fortification a strategic point during the constant border wars that spanned the last three centuries of The
'Reconquista'. This location easily connected to the Almanzora Valley and, at the same time, it allowed to protect the entrance to Los Vélez (Sánchez, 1999). After the fall of the Nasrid Kingdom, its nature as a fortification persisted in Castilian times, as evidenced by the chronology of events of the war against the Moors in the 16th century (Sánchez, 2002). During this century, the 'Alcazaba' was repaired by the Marquis of los Vélez (Carricondo, 2010).

According to the drawing of Oria from the Cadastre of Ensenada, the fortress probably had retained at least its northside walled enclosure in the 18th century (Figure 2). By the mid-20th century, the 'Alcazaba' had the same wall sections on its north side and some sections on its south and east sides (Figures 3, 4 and 5).

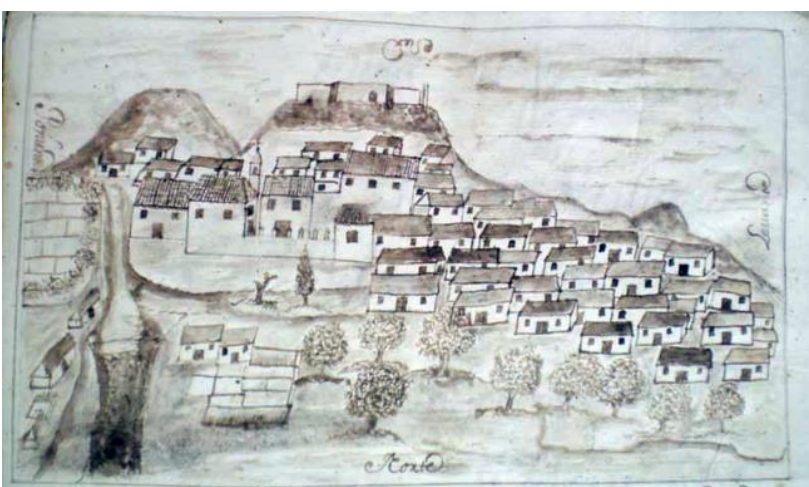

Figure 2. Drawing of Oria village, 1753. The 'Alcazaba' entrance can be seen on the north side. Source: City Council of Oria.

\footnotetext{
* Corresponding author
} 


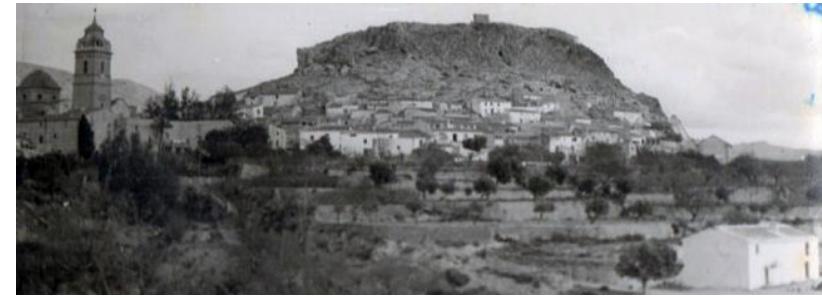

Figure 3. View of Oria in 1950. The 'Alcazaba' wall section can be seen on the southern side. Source: Todocolección 2019.
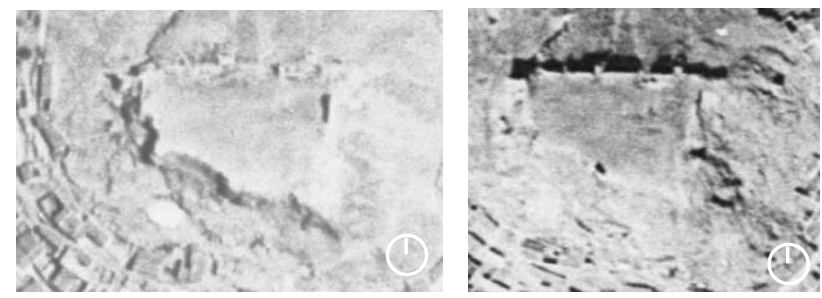

Figures 4 and 5. Orthophoto of the 'alcazaba of Oria'. In the Projection Series A (1946-1947) and Series B (1956-57), the wall sections of the 'Alcazaba' are identified.

Source: IGN'1.

The 'Alcazaba' has been considered protected heritage since 1949. Initially, its status came from the $\operatorname{lax}^{2}$ Decree of the BOE of the 22 of April of 1949 on the Protection of Castles and, later, from Law 16/1985 on Spanish Historical Heritage, which registers it as an Asset of Cultural Interest (BIC by its Spanish acronym) under the legal classification of Monument. However, at the beginning of the 21 st century, the only intervention ${ }^{3}$ carried out in the 'Alcazaba' has been the conditioning of the surroundings for tourist visits. No action has ever been taken to conserve the wall structures, because of that they are currently in an advanced degradation state (Figure 6).

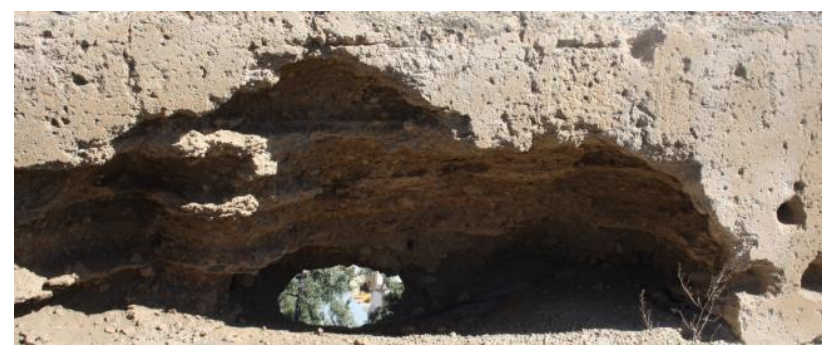

Figure 6. Loss of mass and wall section in north side of the 'Alcazaba' rammed-earth wall. Photography: Jorge Moya Muñoz 2019.

1 Instituto Geográfico Nacional, regional service of National Centre of Geographic Information

2 Its first article prevents any action that would alter its nature or cause it to collapse, but in no case does it provide for any kind of intervention: "these venerable vestiges of the past ... it is impossible, except in exceptional cases, not only to reconstruct them, but even to carry out works to preserve them"...

3 During the last third of the 20th century, pine trees were repopulated inside the Alcazaba and, in the 21 st century, work has been done to install telephone antennas.

\section{RESEARCH DEVELOPMENT}

\subsection{Objetives}

One of the purposes of this work is to broaden the knowledge about the rammed-earth constructions of eastern Andalusia, especially representative village's fortifications. From the architectural perspective, the alcazaba of Oria is a model that allows analyzing its material components, the rammed-earth wall constructive characteristics and the wall conservation state. In addition, this research allows us to have an integral approach to the wall consolidation works. In this first research phase, one of the existing wall sections is selected: the rammed-earth wall located on the eastern side of the fortified enclosure (Figure 7).

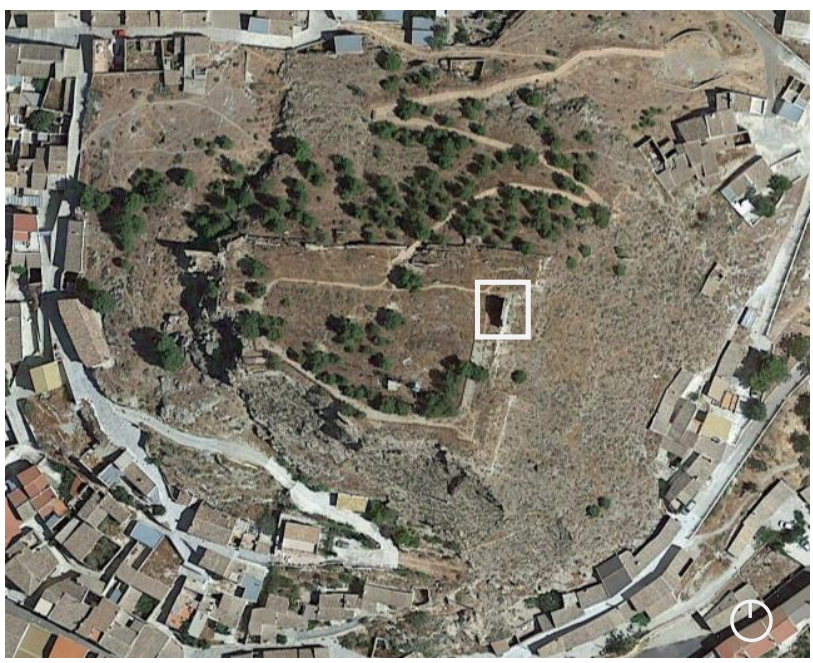

Figure 7. Location of the eastern section of the 'Alcazaba' wall. Source: Landsat / Copernicus. IBCAO.

\subsection{Methodology}

The methodological proposal is based, on the one hand, on the stratigraphic analysis of the wall of alcazaba of Oria; and, on the other, on its constructive-typological definition, to finally determine its conservation state by the identification of the damages. The work developed uses the photogrammetry and the point cloud analysis, as an objective to make extensive use of digital tools in the generation of heritage knowledge, and is included in action line D1 of the TUTSOSMOD $R+D+i$ project.

\subsection{Data collection}

The wall data was taken using the indirect method of photogrammetry. Two types of photographic equipment were used: a Canon EOS 1000D 10.1-megapixel digital reflex camera with an 18-55 IS lens, and a 12-megapixel integrated camera on a FIMI X8 SE RC drone.

Firstly, three control points were positioned $1 \mathrm{~m}$ apart on the lower third of the inner surface of the selected section of wall using laser levels and plumb bobs. These three targets subsequently made it possible to scale and establish a relative coordinate axis with which to suitably orientate the wall in the graphic restitution program (Figure 8). 


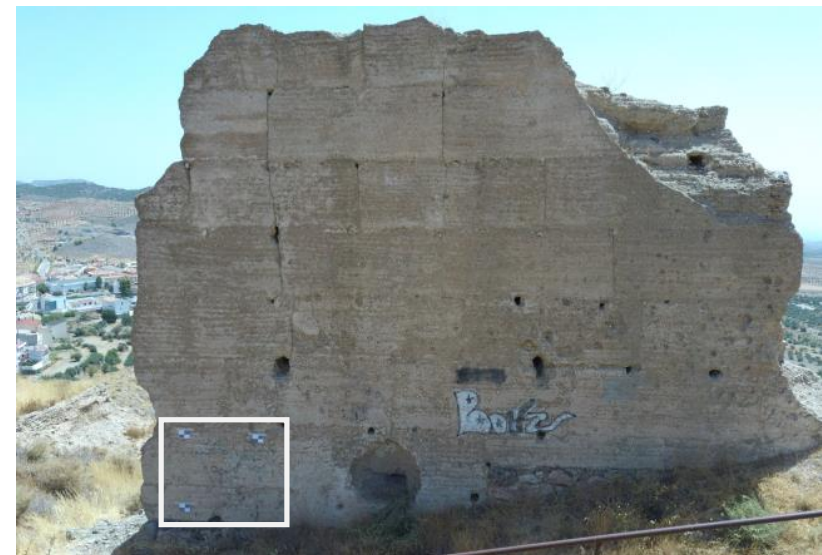

Figure 8. Control points location in the wall section studied. Photography: Félix Pérez Moreno 2019.

\subsection{Graphic restitution}

From a total of 148 photos, all the images were restored using the Agisoft PhotoScan Professional software (Figure 9). Once the wall images had been processed, a cloud of points forming its three-dimensional model was created in order to be exported as a txt file to Recap PRO 2019. Thus, the file that defines the graphic base to work in Autocad 2019 had been completely extracted.

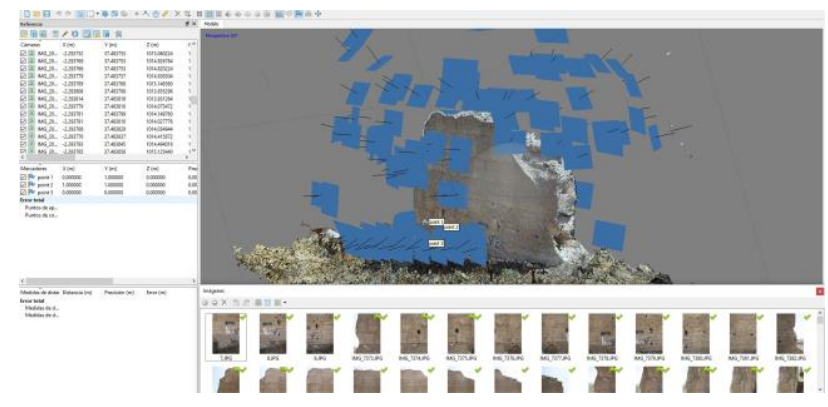

Figure 9. Markers location and photographs position in the Agisoft software. Source: Authors 2019.

\subsection{Stratigraphic analysis}

Once the 3D point cloud is created, the architectural stratigraphic analysis of the specified wall section is proposed. This method is interesting for the complete Oria`s 'Alcazaba' rammed-earth wall study, due to its historical value (Caballero, 1995). Therefore, we propose an approach to the stratigraphic analysis defined by Mileto and Vegas (2010). This analysis difference the process into two phases: a first phase of data identification and transcription and a second one of stratigraphic interpretation.

The following coding has been used for the numbering of the elements: the hundreds for the Stratigraphic Units ${ }^{4}$ (SU) in the wall; the hundreds next to a letter for the actions that define the chronological processes of the section of wall considered; the tens for the Structure (S); and the units for the Structural

4 Brogiolo (1988) defines the SU as the minor element that can be stratigraphically individualised on the basis of its composition and construction technique. Rouco and Martin (2018) define the Structure as the grouping of the SU that fulfils the same structural function, and the SC as the set of Ss that brings together a physical space, which would be the Alcazaba.
Complex (SC) that would define the physical space of the 'Alcazaba' as the sum of the totality of Ss.

In the first phase, the graphic support used to develop data transcription is defined by the three-dimensional point cloud. Based on this data, the SUs (negative strata or interfaces) are defined and the actions that will later serve to propose the chronological study are identified.

\begin{tabular}{|l|c|c|c|c|c|c|}
\hline SU & 101 & 102 & 103 & 104 & 105 & 106 \\
\hline Type & Strata & Strata & $\begin{array}{c}\text { Inter } \\
\text { face }\end{array}$ & $\begin{array}{c}\text { Inter } \\
\text { face }\end{array}$ & $\begin{array}{c}\text { Inter } \\
\text { face }\end{array}$ & $\begin{array}{c}\text { Inter } \\
\text { Face }\end{array}$ \\
\hline Action & A001 & $\begin{array}{c}\text { A002 } \\
\text { A003 }\end{array}$ & A004 & A004 & A005 & A006 \\
\hline
\end{tabular}

Table 1. Relationship between SUs and S01 Activities. Source: Authors 2019.

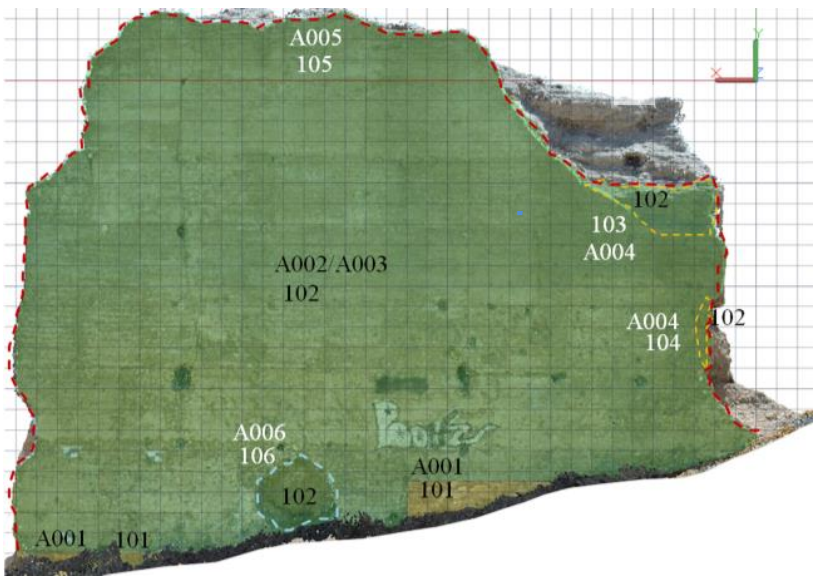

Figure 10. Intrados wall view: S01 SUs identification and demarcation. Source: Authors 2019.

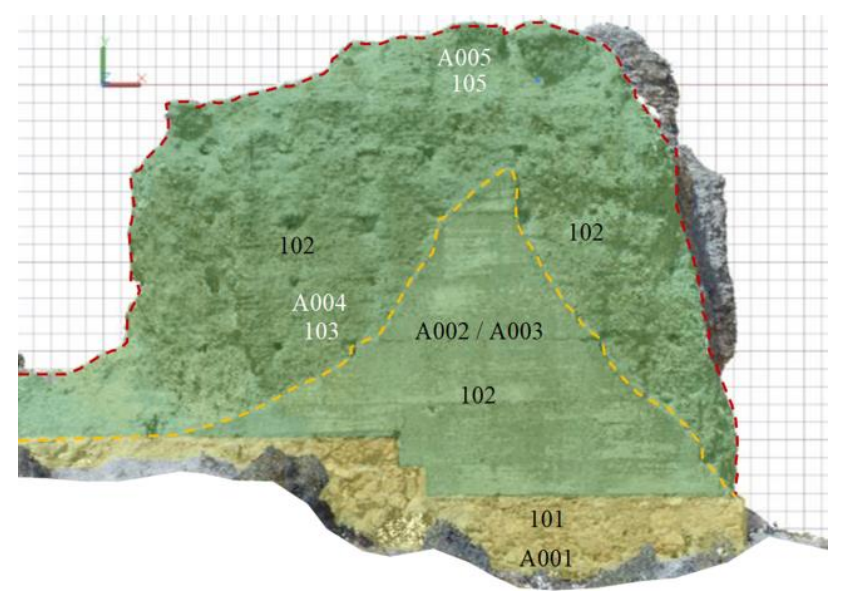

Figure 11. Extrados wall view. S01 SUs identification and demarcation. Source: Authors 2019.

The rammed-erath wall section considered is part of S01. The identification of the SUs that define it stratigraphically would start with the SU of the foundation. However, SU101 has been considered the starting point because it is impossible to test it as SU101 overplats with the wall linked to the A001 action. This action corresponds to the process prior to the wall construction. The following is SU 102, associated with the rammed-earth wall and A002 and A003 construction actions of the wall structure. The loss of whitewash and mass of the rear wall is related to SUs 103, 104 and 106, interfaces that 
cause SU101 to lose coating. Both SU103 and SU104 are related to actions A004 and SU106 to A006. Finally, SU105 is related to the wall mass loss associated with action A005. (Figure 10).

The stratigraphic relationships defined in the wall section studied are described below considering and expanding the types of relationships proposed by Caballero 1995: the elements spatial situation in contact; the construction process; and the temporal sequence divided into temporal phases related to the actions linked to the construction processes, of use and deterioration of the wall, and on the other hand, into stages which define more generic time periods (Table 2).

\begin{tabular}{|c|c|c|c|c|c|c|c|}
\hline & SU & 101 & 102 & 103 & 104 & 105 & 106 \\
\hline 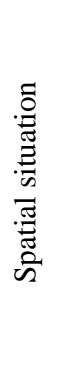 & $\begin{array}{l}\text { On top of } \\
\text { Underneath } \\
\text { Matches } \\
\text { Borders }\end{array}$ & 102 & $\begin{array}{l}101 \\
\\
\\
103 \\
104 \\
105 \\
106\end{array}$ & 102 & 102 & 102 & 102 \\
\hline 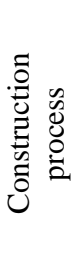 & $\begin{array}{l}\text { Supports } \\
\text { Supports in } \\
\text { Covers } \\
\text { Discovers } \\
\text { Empties to }\end{array}$ & 102 & 101 & 102 & 102 & 102 & 102 \\
\hline 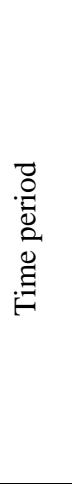 & $\begin{array}{l}\text { Prior to } \\
\text { Contemporary } \\
\text { After to }\end{array}$ & $\begin{array}{l}102 \\
103 \\
104 \\
105 \\
106\end{array}$ & $\begin{array}{l}103 \\
104 \\
105 \\
106 \\
\\
\\
\\
101\end{array}$ & $\begin{array}{l}104 \\
101 \\
102\end{array}$ & $\begin{array}{l}103 \\
101 \\
102\end{array}$ & $\begin{array}{l}101 \\
102 \\
103 \\
104\end{array}$ & $\begin{array}{l}101 \\
102 \\
103 \\
104 \\
105\end{array}$ \\
\hline 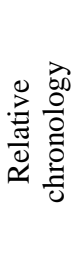 & $\begin{array}{l}\text { Prior to } \\
\text { Contemporary } \\
\text { After to }\end{array}$ & 102 & 101 & $\begin{array}{l}104 \\
105 \\
106 \\
101 \\
102\end{array}$ & $\begin{array}{l}103 \\
105 \\
106 \\
101 \\
102\end{array}$ & $\begin{array}{l}103 \\
104 \\
106 \\
101 \\
102\end{array}$ & $\begin{array}{l}103 \\
104 \\
105 \\
101 \\
102\end{array}$ \\
\hline
\end{tabular}

Table 2. Stratigraphic relations of direct physical relationship.

Accordingly, after analyzing and understanding the relationships between SUs and actions, the second study phase that allows interpretated these relationships in chronological orden is proposed. The result is exemplified by the Harris matrix (Harris, 1986) and is related to the colour representation of Figures 10 and 11 (Table 3).

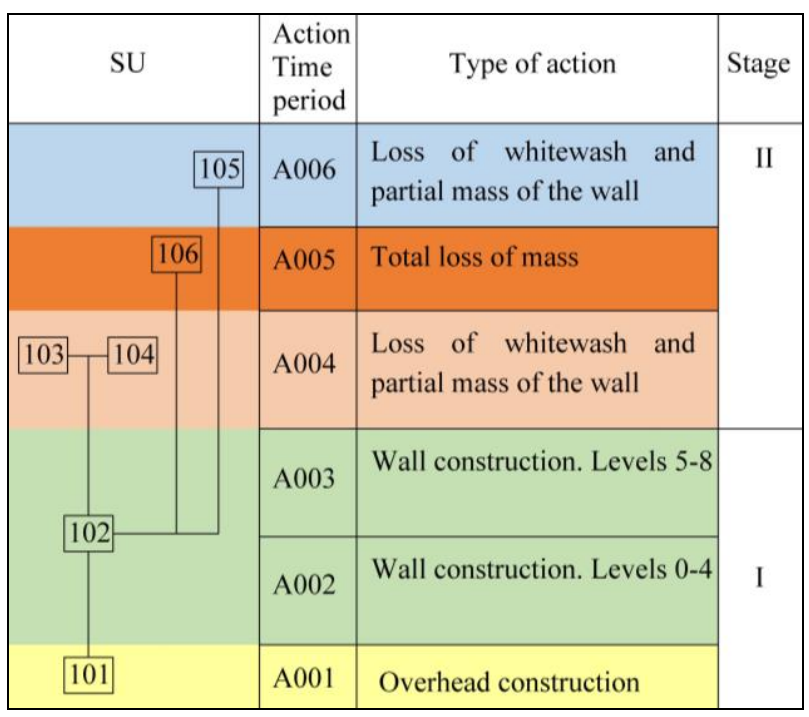

Table 3. Relationship with the Harris matrix. Source: Authors 2019.

\subsection{Constructive-typological definition}

The next step is the wall constructive-typological definition; the three categories proposed by Graciani and Tabales (2008) have been first taken into account: compositional, material and measures of the rammed-earth blocks or rammed-earth wall module for its classification. According to its compositional character, this wall section is considered a simple rammed-earth wall design because the rammed-earth blocks are superimposed without any articulating element. Regarding its basics material components, it is a real rammedearth wall with a high presence of lime binder ${ }^{5}$, while recognising a significant presence of crushed ceramic fragments. Finally, the size of the rammed-earth block of the wall alternates the low module ${ }^{6}$ (between $80-85 \mathrm{~cm}$ ) and the high module (between $85-95 \mathrm{~cm}$ ).

In order to explain the parameters mentioned above in detail, the taxonomic and dimensional classification proposed by Gil and Maldonado (2015) has been considered as a methodological reference, where the different ways of building historical wall are characterised; along with the constructive characterisation of the Almohad rammed-earth wall structures proposed by Canivell and Graciani (2015); as well as the works of Sanchez i Signes (2013) and his study of the constructive impressions associated with that constructive technique.

It is necessary to specify that the foundation on which the wall rests cannot be raised by photogrammetry. To properly define it, it would be necessary to carry out test pits and surveys, which are not feasible at this stage of the research. However, it is possible to discern its staggered construction by adapting it to the mountain topography, based on the understanding of its superimposition. It was built using stone masonry taken from lime mortar. In the wall section studied, a variable height of up to one metre can be observed. (Figure 12).

5 The organoleptic study shows a high presence of lime so we could consider the resulting material as a lime concrete (Mileto, 2014).

6 According to Graciani and Tabales (2008), the low module is linked to the codo rassani, equivalent to $58.93 \mathrm{~cm}$, while the high module is related to the $47.14 \mathrm{~cm}$ of codo mamuni. 


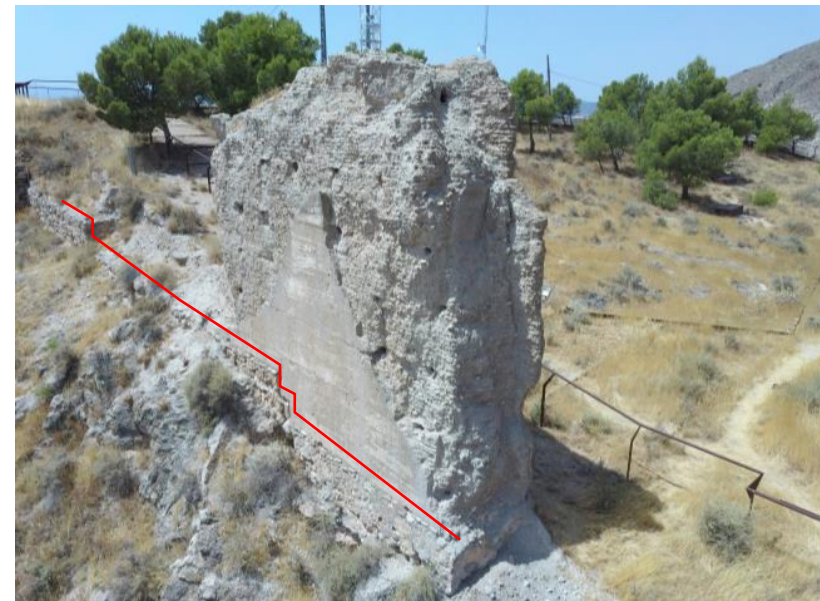

Figure 12. Staggered line from the top of the 'Alcazaba' wall. Photography: Félix Pérez Moreno 2019.

Once an approximation of the foundation has been made, the wall is studied. In terms of configuration, the wall section measuring approximately $8.5 \times 6.5 \mathrm{~m}^{2}$ is made up of direct contact rammed-earth walls (except at the start of the wall, where we can see regulating aggregates), which form a structure that supports the overlay. The identification of the rammed-earth walls has been carried out, listing them under the letters TP and followed by a number, so that later their metric, formal and constructive aspects can be analysed. The rammed-earth blocks total number is 28 units, according to the vertical construction joints that have been observed. In 13 of them, their dimensions can be measure (length $\mathrm{x}$ height). For their characterisation, a number is assigned and associated with the level of their base -or construction elevation marks- (Figure 13). The levels are the following: level 0 , corresponding to $+0.00 \mathrm{~m}$ ( $1013 \mathrm{~m}$ above sea level), level 1 , elevation $+0.47 .5 \mathrm{~m}$, level 2 , elevation $+0.80 \mathrm{~m}$, level 3 , elevation $+1.26 \mathrm{~m}$, level 4 , elevation $+2.08 \mathrm{~m}$, level 5 , elevation $2.89 \mathrm{~m}$, level 6 , elevation $+3.82 \mathrm{~m}$, level 7 , elevation $+4.58 \mathrm{~m}$, and level 8 , elevation $+5.54 \mathrm{~m}$. (Table 4).

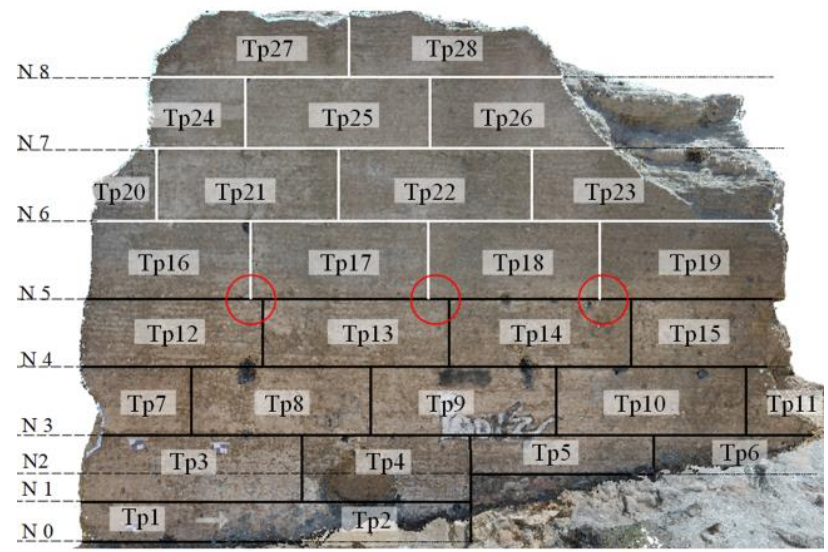

Figure 13. Intrados wall view: identification of the walls and levels. Source: Authors 2019.

Although, in order to obtain definitive results for the dimensions, it would be necessary to consider the size of the boards of the rammed-earth (Graciani and Tabales, 2008), it can be observed how, in the first four levels, the height of the fences would correspond to the low module (black in Figure 13), while in the upper levels it would correspond to the high module (white in Figure 13).

\begin{tabular}{|c|c|c|c|c|c|c|c|}
\hline TP & Level & High & Width & TP & Nivel & High & Width \\
\hline 1 & 0 & 47.5 & - & 15 & 4 & 81.3 & - \\
2 & 0 & 47.5 & - & 16 & 5 & 92.7 & - \\
3 & 1 & 80.0 & 212.6 & 17 & 5 & 92.7 & 211.9 \\
4 & 1 & 80.0 & 200.7 & 18 & 5 & 92.7 & 203.7 \\
5 & 2 & 46.3 & 218.4 & 19 & 5 & 92.7 & - \\
6 & 2 & 46.3 & - & 20 & 6 & 86.9 & - \\
7 & 3 & 81.7 & - & 21 & 6 & 86.9 & 216.6 \\
8 & 3 & 81.7 & 213.7 & 22 & 6 & 86.9 & 230.9 \\
9 & 3 & 81.7 & 221.2 & 23 & 6 & 86.9 & 218.0 \\
10 & 3 & 81.7 & 225.5 & 24 & 7 & 85.4 & - \\
11 & 3 & 81.7 & - & 25 & 7 & 85.4 & 220.3 \\
12 & 4 & 81.3 & - & 26 & 7 & 85.4 & 215.0 \\
13 & 4 & 81.3 & 221.9 & 27 & 8 & - & - \\
14 & 4 & 81.3 & 216.8 & 28 & 8 & - & - \\
\hline \multicolumn{7}{|c|}{ Thickness of the rammed- } & \multicolumn{3}{|c|}{$1.66 \mathrm{~cm}$ (approximately } \\
\multicolumn{7}{|c}{ earth walls } & \multicolumn{5}{c}{3.5 Mamuni cubits) } \\
\hline
\end{tabular}

Table 4. Rammed-earth walls dimensional characterization ${ }^{7}$. Values in cm. Default values in grey. Source: Authors 2019.

Another significant aspect to analize is the relationship between the rammed-earth blocks of the wall. The rammed-earth blocks of the first four levels have a series of vertical joints that allows the correct locking of the wall. In turn, from the sixth level and above, the same happens. However, it is at level five where there is a discontinuity between levels (red in Figure 13), producing the almost vertical overlap of putlogs (or, in their absence, the putlog holes). This could be due to the construction sequence of the wall, executed up to the level 5 level along the entire length of the wall and the subsequent elevation of the upper levels.

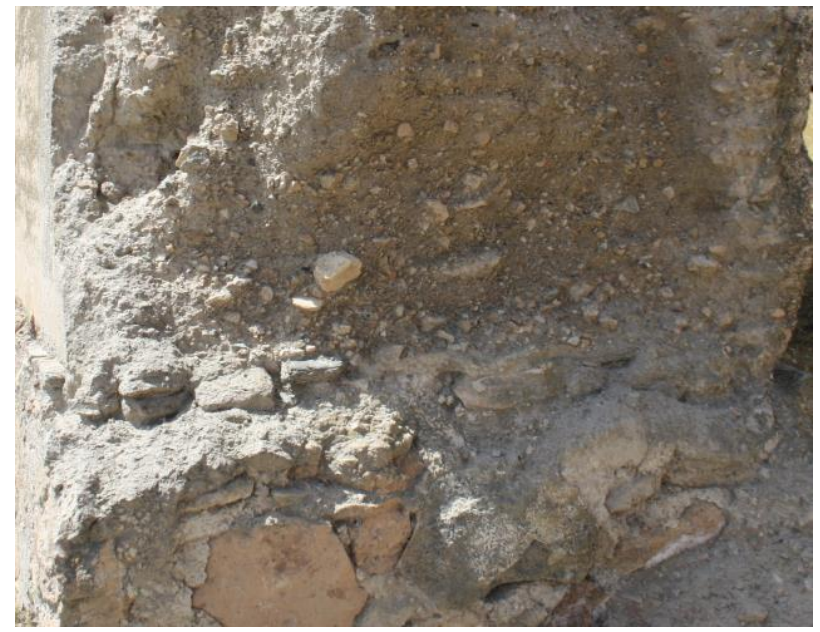

Figure 14. Wall section view: the layer of stones for the regularisation of the rammed-earth wall on the top can be observed. The whitewashing, the interior material components and the aggregates measure used can also be seen. Photography: Jorge Moya Muñoz 2019.

The rest of the parameters considered for the constructivetypological characterisation are defined below: they used local soil to build the rammed-earth wall, with a significant presence of lime and ceramic material; by an organoleptic test detect that the granulometry is compensated with a maximum aggregate size of $15 \mathrm{~cm}$. This mass is compacted by means of layering in 6$8 \mathrm{~cm}$ coats, assuming a total of 10-13 coats for each low-module rammed-earth and 11-15 coats for those of high modules. The

\footnotetext{
7 As specified in the text, TP23 and TP26 modules measures are hypotheses obtained from the development of the research.
} 
wall section finishing is whitewashing on both sides, with a thickness which varies between 13-20 cm (Figure 14).

Finally, the parameters related to main function that the rammed earth blocks have in the execution of the wall have been studied. Regarding the needles, they are always through and are found throughout the section fenced within the lower thread, with a slate sky without laterite rocks to allow their subsequent recovery. The square hole or putlogs hole of these varies only at the base of the wall, where there are rectangular sections of $7 \mathrm{x}$ $3 \mathrm{~cm}^{2}$. In the rest of the wall, square section holes of approximately $10 \times 10 \mathrm{~cm}^{2}$ have been identified (Figure 15-16).
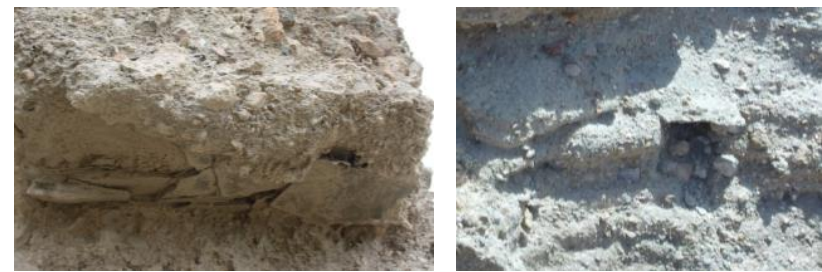

Figures 15 and 16. Square section hole impressions with a slab roof. Photography: Félix Pérez Moreno 2019.

The separation distance between the needles is relatively constant, with distances ranging from 90 to $120 \mathrm{~cm}$ (Figure 17). Their length varied between 176 and $181 \mathrm{~cm}$, considering that a dimension of about $10-15 \mathrm{~cm}^{8}$ stands out on each side. This measure funtion are not only the need to support the sacking, but also the possibility of supporting a scaffolding structure.

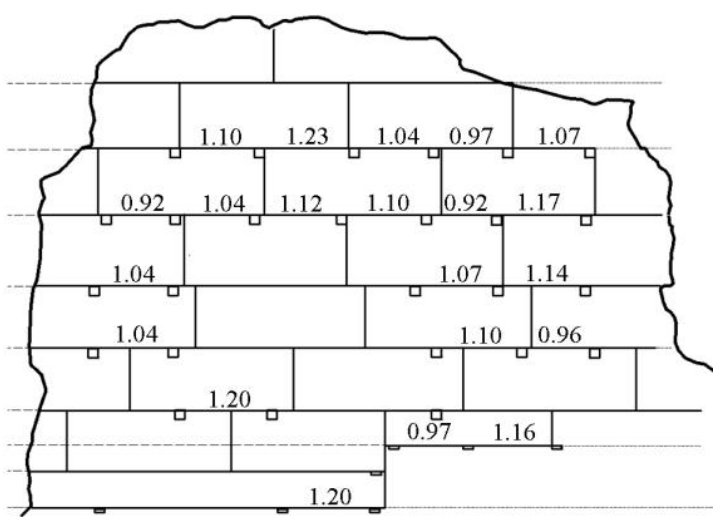

Figure 17. Location and distances between putlogs holes of the rammed-earth wall. Extrados wall. Dimensions in $\mathrm{cm}$. Source: Authors 2019.

Analysing the putlogs, it is evident that the rammed-earth wall was built according to two different orderly sequences. From level 0 to 4 , there are two putlogs for each rammed-earth wall, while from level 5 there are 3 putlogs for each wall. (Figures 17 and 18).

Therefore, it can be deduced that each rammed-earth wall was supported by three putlogs. This evidences an important level of planning. Thus, a wall would use the last putlog of the previous wall to form the next one (Figure 18 and 19). From this premise, the hypothetical dimensions of TP23 and TP26 rammed-earth blocks can be completed by knowing the holes that were used for their execution.

8 According to Canivell y Graciani 2015, this dimension is used to characterize the spires of Christian wall constructions. In turn, they consider that the sections of $7-10 \times 7-10 \mathrm{~cm} 2$ are could used to the scaffolding functions.

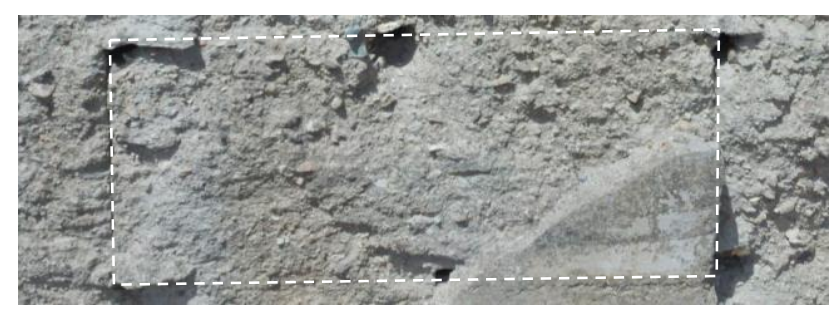

Figure 18. Demarcation of TP22 rammed-earth block corresponding to three ordered putlogs. Photography: Félix Pérez Moreno 2019.

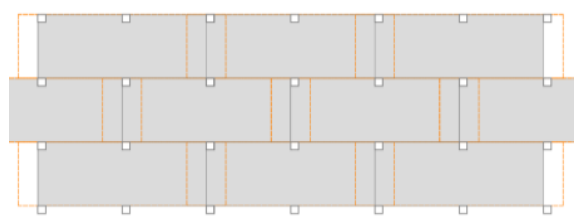

Figure 19. Formwork overlapping proposal and three ordered sequences execution of the rammed-earth blocks in the wall upper levels. Source: Authors 2019.

After the putlogs are removed, the hole they leave is covered with a same wall material mortar and the surface is smoothed out while still fresh (Gallego, 2014). Besides that, to ensure adherence when applying the coating, stones are inserted to facilitate its application (Figure 20).

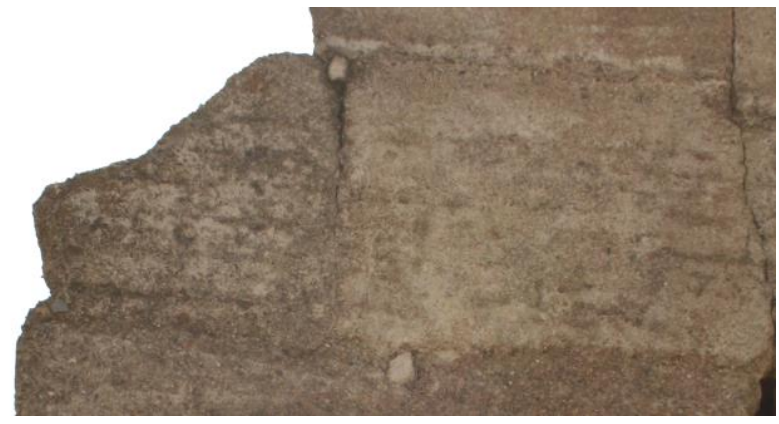

Figure 20. View the putlog holes filled with stones. Photography: Jorge Moya Muñoz 2019.

Furthermore, on the western wall section no markings can be seen that would allow us to know the number and measure of the formwork panels. The mark on the headboard of the TP3, TP19 and TP21 coatings can be seen (Figure 21). This mark has made it possible to determine the dimensions of TP3 and TP19 coatings.

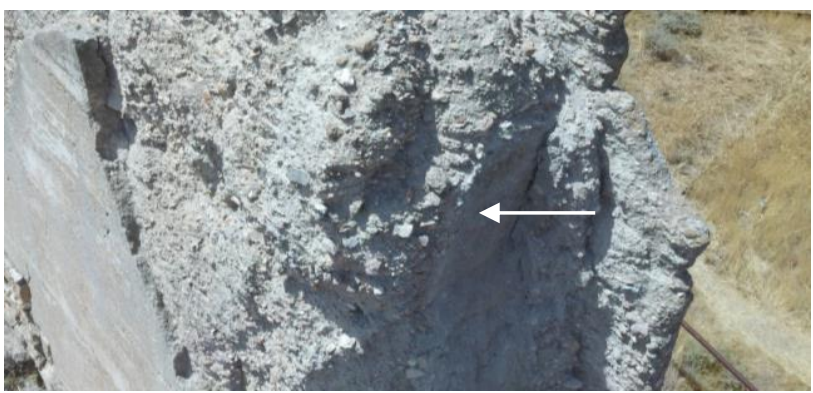

Figure 21. Mark of the headboard of rammed-earth wall 21. Photography: Félix Pérez Moreno 2019. 
In addition, a $7 \mathrm{~cm}$ deep semi-circular section can also be seen on the TP2 rammed-earth wall which makes it possible to deduce that it was not necessary to place the headboard on this rammed earth wall. This hypothesis is reaffirmed because the mark corresponds to the height of the wall (Figure 22).

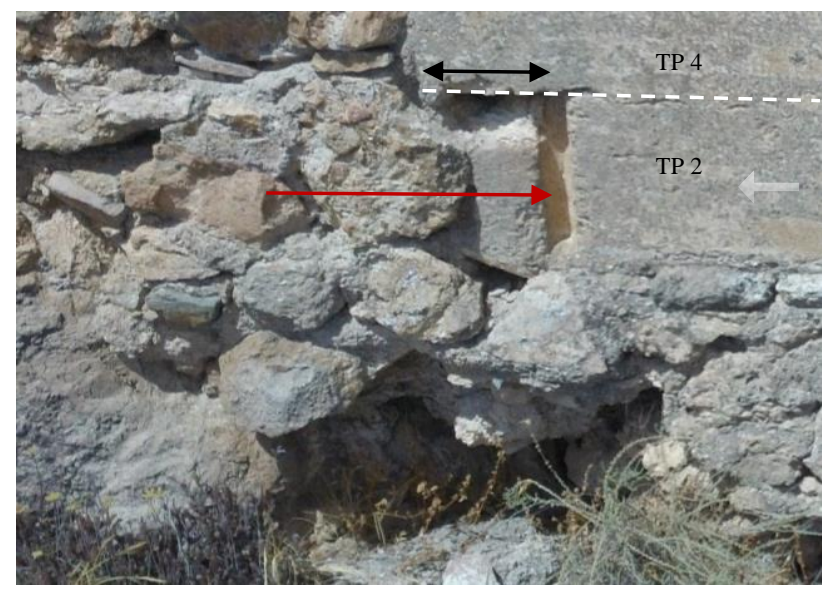

Figure 22. Semi-circular pattern on TP 2. Photography: Félix Pérez Moreno 2019.

In turn, this mark indicates that the execution direction of the TP2 rammed-earth wall is towards the overlay that served as a border (Figures 13 and 22). It can also be deduced that the formwork would have been at least $14 \mathrm{~cm}$ behind this pattern.

\subsection{Approximation to the wall pathological analysis}

In the section of the wall studied, physical, mechanical and chemical damage was observed, most of it related to direct and constant exposure to atmospheric agents and others to anthropic action. The table 5 is a simplified summary of the wall section damages according to their location, based on the classification made by Canivell (2011):

\begin{tabular}{|l|l|l|}
\hline \multicolumn{2}{|l|}{ Type of damage } & Location \\
\hline \multirow{3}{*}{ Physical (P) } & Dirt Deposit & Widespread \\
& Dirt washed away & Widespread \\
\cline { 2 - 3 } & Atmospheric Erosion & Widespread \\
\hline \multirow{3}{*}{ Chemical (C) } & Support crack (M1) & Intrados \\
\cline { 2 - 3 } & $\begin{array}{l}\text { Finish crack } \\
\text { Finish detachment and } \\
\text { partial loss of mass (M2) } \\
\text { Erosion (M3) }\end{array}$ & $\begin{array}{l}\text { Intrados / } \\
\text { Extrados } \\
\text { Intrados }\end{array}$ \\
\hline & Banding (C2) & Topping out \\
Intrados
\end{tabular}

Table 5. Damages to the west wall. Source: Authors 2019.
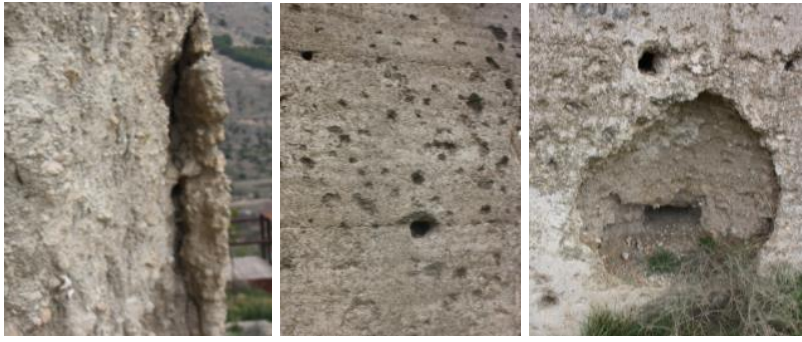

Figures 23, 24 and 25. Loss of whitewash as a result of internal wall washing, shrapnel marks and the presence of plant organisms are shown in sequence. Photography: Félix Pérez Moreno and Jorge Moya Muñoz 2019.

In Figure 26 and 27 localised damage in a simplified manner for the extrados and the intrados of the rammedearth wall.

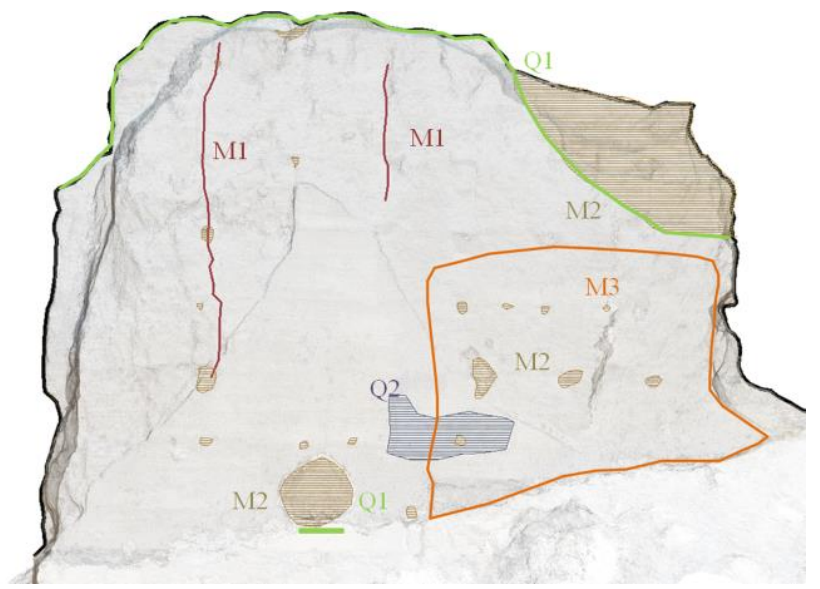

Figure 26. Intrados wall view: damages identification. Source: Authors 2019.

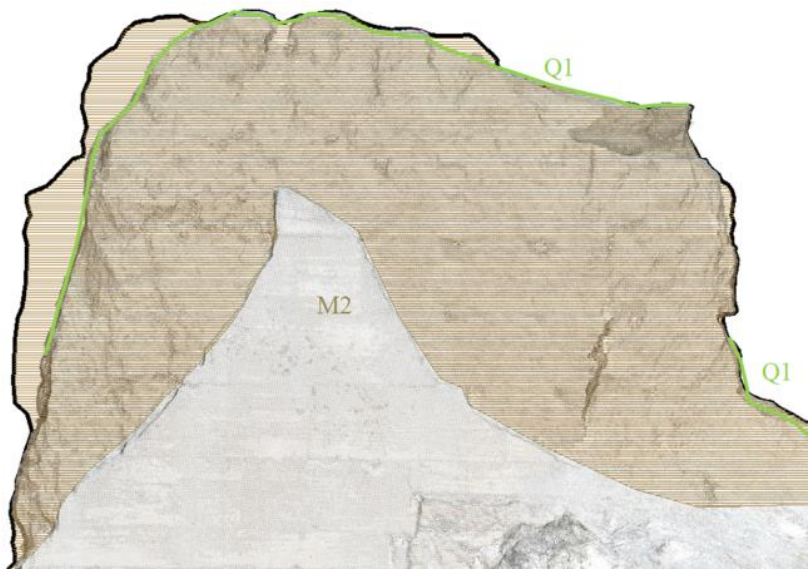

Figure 27. Extrados wall view: damages identification. Source: Authors 2019.

\section{CONCLUSIONS}

Photogrammetry is a tool that allows to create a threedimensional model as a graphic base and makes it possible to go deeper into the stratigraphic analysis and the constructivetypological definition, as well as the alcazaba of Oria wall pathological state. 
The constructive and typological aspects of Almohad and Nasrid architecture - a period in which the original 'Alcazaba' is dated - allow us to deduce that the wall section considered was part of an intervention carried out during a period of Castilian settlement. This hypothesis makes sense if we consider the militaristic intensity of the 16th century, when there is repair work evidence.

However, this hypothesis must be endorsed. First of all, this entails the stratigraphic analysis of the 'Alcazaba's' structural complex, the constructive-typological definition of the whole structure, and an exhaustive study of the materials by means of laboratory techniques are necesary. From these results, it is possible to establish a transversal study among the fortifications of Almanzora, with the aim of proposing a chronotypological proposal that completes the existing research on the fortifications of the Almanzora Valley.

These works will be fruitless if an exhaustive pathological study is not prioritised. This study will give rise to an emergency protocol for the consolidation of the section of the wall and the other sections of the alcazaba of Oria.

\section{REFERENCES}

Brogiolo, G. 1988. Archeolologia dell'edilizia storica. Como. New Press.

Caballero Zoreda, L. 1995. Método para el análisis estratigráfico de construcciones históricas o" lectura de paramentos". Informes de la Construcción, 46(435), 37-46.

Canivell, J., Graciani García, A. 2015. Caracterización constructiva de las fábricas de tapia en las fortificaciones almohades del antiguo Reino de Sevilla. Arqueología de la Arquitectura, (12), e025.

Canivell, J. 2011. Methodology of diagnosis and characterization historical rammed-earth walls. $\mathrm{Ph}$ Tesis. Seville, Dept. of Architectural Construction II, Universidad de Sevilla, Seville, Spain.

Castellón Sánchez del Pino, A. 2017. Castillos y atalayas del Almanzora. Instituto de Estudios Almerienses.

Decreto de 22 de Abril de 1949, sobre protección de los castillos españoles. Boletín Oficial del Estado, 125, del 5 de Mayo de 1949. (2058-2059). Text extracted from https://www.boe.es/datos/pdfs/BOE//1949/125/A0205802059.

Gallego Roca, F. J. 2014. Muralla de la Alberzana, Granada (1998-2009). La restauración de la tapia en la Península Ibérica: Criterios, técnicas, resultados y perspectivas. Valencia/Lisboa: TC Cuadernos/Argumentum. (250-255).

Gil Crespo, I. J., Maldonado Ramos, L. 2015. Hacia una taxonomía constructiva de las tapias de tierra y fábricas encofradas históricas. Informes de la construcción, 67(538), $\mathrm{e} 086$.

Graciani García, A., Tabales Rodríguez, M. A. 2008. El tapial en el área sevillana. Avance cronotipológico estructural. Arqueología de la Arquitectura, (5), 135-158.

Harrys, E. 1986. Principios de estratigrafía arqueológica. Ed. Crítica. Barcelona.
Ley 16/1985, del 25 de junio de 1985, sobre el Patrimonio Histórico Español. Boletín Oficial del Estado, 155, del 29 de Junio de 1985. (20342-20352).

Mileto, C., Vegas, F. 2010. El análisis estratigráfico: una herramienta de conocimiento y conservación de la arquitectura. In Actas del congreso Arqueología aplicada al estudio e interpretación de edificios históricos. Últimas tendencias metodológicas. Ministerio de Cultura, Subdirección General Técnica de Publicaciones, Información y Documentación, Madrid, España. 145-158.

Mileto, C., Vegas, F., Cristini, V., García Soriano, L. 2014. La tapia en la península ibérica. La restauración de la tapia en la Península Ibérica. Criterios, técnicas, resultados y perspectivas. Valencia/Lisboa: TC Cuadernos/Argumentum. (32-51).

Rouco Collazo, J., Martín Civantos, J.M., Benavides López, J.A. 2018. Análisis arqueológico de la torre-puerta de la alcazaba de Guadix (Granada). Arqueología de la Arquitectura, (15), e72.

Sánchez i Signes, M. 2013. El refugio en altura andalusí de Vilella (Almiserat, Valencia), un ejemplo de arquitectura defensiva rural en el ámbito centro-meridional valenciano (ca. 1150-1250). Arqueología de la Arquitectura, (10), e005.

Sánchez Ramos, V. 1999. La fortaleza de Oria y la guerra de los moriscos. Revista velezana, (18), 7-26.

Sánchez Ramos, V. 2002. El II Marqués de los Vélez y la guerra contra los moriscos, 1568-1571. Revista Velezana.

Website www.todocolección. Accessed July 15, 2019.

Website www.ign.es. Accessed September 10, 2019.

Website www.googleearth.com. Accessed July 15, 2019 